\title{
PELAKSANAAN PERJANJIAN SEWA MENYEWA BUSANA DALAM MERIAS WAJAH*
}

\author{
Oleh: \\ Luh Ayu Mistrinda Dewi** \\ Ida Bagus Putra Atmadja, SH., $\mathrm{MH}^{* * *}$ \\ Program Kekhususan Hukum Bisnis \\ Fakultas Hukum Universitas Udayana
}

\begin{abstract}
ABSTRAK
Kebutuhan masyarakat akan busana dan rias wajah semakin meningkat sehingga banyak orang yang menggunakan kesempatan ini untuk menyewakan busana dalam merias wajah. Permasalahan yang sering terjadi pada pelaksanaan perjanjian sewa menyewa busana dalam merias wajah, yaitu pembatalan perjanjian secara sepihak yang dilakukan oleh penyewa. Berdasarkan permasalahan tersebut peneliti melakukan penelitian terhadap faktor-faktor yang mempengaruhi pembatalan perjanjian secara sepihak pada sewa menyewa busana dalam merias wajah dan penyelesaian terhadap pembatalan perjanjian secara sepihak pada sewa menyewa busana dalam merias wajah.

Jenis penelitian yang digunakan adalah penelitian hukum empiris. Pada tulisan ini menggunakan data primer dan data sekunder yang diperoleh melalui teknik studi dokumen dan teknik wawancara. Data yang diperoleh kemudian diolah dan dianalisis secara kualitatif.

Berdasarkan penelitian yang dilakukan maka diperoleh hasil, bahwa terdapat 2 (dua) faktor penyebab terjadinya pembatalan perjanjian secara sepihak, yaitu faktor internal dan faktor eksternal. Faktor internalnya, yaitu kurangnya pemahaman masyarakat tentang perjanjian lisan. Faktor eksternalnya, yaitu terdapat tempat lain yang menyewakan busana lebih murah, busana yang disewa cacat, dan barang yang disewa belum dikembalikan oleh pihak penyewa yang

* Makalah ilmiah yang berjudul Pelaksanaan Perjanjian Sewa Menyewa Busana Dalam Merias Wajah, yang merupakan makalah ilmiah di luar ringkasan skripsi.

** Penulis pertama dalam penulisan makalah ilmiah ini ditulis oleh Luh Ayu Mistrinda Dewi, merupakan mahasiswa Fakultas Hukum Universitas Udayana.

*** Penulis kedua dalam penulisan makalah ilmiah ini ditulis oleh Ida Bagus Putra Atmadja, SH., MH., selaku Pembimbing Akademik dari penulis pertama di Fakultas Hukum Universitas Udayana
\end{abstract}


terdahulu. Penyelesaian pembatalan perjanjian secara sepihak dilakukan dengan cara kekeluargaan.

\title{
Kata Kunci: Pelaksanaan, Perjanjian Sewa Menyewa, dan Pembatalan Sepihak.
}

\begin{abstract}
The need for clothing and makeup is increasing so many people are renting out clothes in makeup. Problems that often occur in the implementation of the lease agreement to rent clothes in makeup is the unilateral cancellation of agreements made by tenats. The Researcher conducted a research of the factors that influence the cancellation of the lease agreement to clothing in makeup unilaterally and settlement of unilateral agreement cancellation on the lease agreement the clothes in makeup.

This type of research used is empirical legal research. In this paper used primary data and secondary data obtained through study document techniques ad interview techniques. The data obtained is then processed and analyzed qualitatively.

Based on the research conducted obtained result that there are 2 factors causing the unilateral cancellation of the lease agreement is a internal factor and external factors. Internal factor, were that many people did not know that oral agreements had legal power. External factors contsist of other places that rent out cheaper clothes, the rented clothes are damaged, and the items rented have not been retuned by the previous tenants. The cancellation of the contract unilaterally in the lease agreement to rent clothes in makeup is done in a family manner.
\end{abstract}

\section{Keywords: Implementatation, Lease Agreement, and Unilateral Canceling.}

\section{Pendahuluan}

\subsection{Latar Belakang}

Setiap orang bebas untuk melakukan perjanjian karena ada asas kebebasan berkontrak. Asas kebebasan berkontrak dapat disimpulkan dari Pasal 1338 KUH Perdata yang menyebutkan bahwa, 
"Semua persetujuan yang dibuat sesuai dengan undang-undang berlaku sebagai undang-undang bagi mereka yang membuatnya. Persetujuan ini tidak dapat ditarik kembali selain dengan kesepakatan kedua belah pihak, atau karena alasan-alasan yang ditentukan olah undang-undang. Persetujuan harus dilaksanakan dengan itikad baik". Pasal 1338 KUH Perdata dijadikan landasan bagi setiap orang untuk melakukan perjanjian dalam bentuk apa pun. Perjanjian yang dibuat harus memenuhi semua ketentuan dalam Pasal 1320 KUH Perdata mengenai syarat sahnya perjanjian. ${ }^{1}$

Salah satu bentuk perjanjian yang sering dilakukan adalah perjanjian sewa menyewa. Subekti menjelaskan bahwa perjanjian sewa menyewa adalah suatu perjanjian yang dilakukan antara penyewa dengan pihak yang menyewakan, pihak penyewa diberikan kebebasan untuk menikmati obyek perjanjian sewa menyewa selama waktu yang telah ditentukan dalam perjanjian tersebut namun pihak penyewa memiliki kewajiban untuk membayar biaya sewa sesuai dengan kesepakatan. ${ }^{2}$

Salah satu perjanjian sewa menyewa yang sering dilakukan saat ini, yaitu perjanjian sewa menyewa busana dalam merias wajah. Saat melakukan perjanjian sewa menyewa tidak diperkenankan melakukan pembatalan perjanjian secara sepihak karena perjanjian tersebut mengikat para pihak yang membuatnya. Pembatalan suatu perjanjian dapat dilakukan berdasarkan Pasal 1338 KUH Perdata

\footnotetext{
${ }^{1}$ Ketut Ariadi dan I Dw. Nym. Rain Asmara P, 2010, Implementation Ketentuan-Ketentuan Hukum Perjanjian Kedalam Perancangan Kontrak, Udayan Press, Denpasar, h. 51.

2 A. A. Dalem Jagat Krisno, Ni Ketut Supasti Dharmawan, dan A. A. Sagung Wiratni Darmadi, 2015, "Akibat Hukum yang Ditimbulkan Dari Wanprestasi Dalam Perjanjian Autentik Sewa Menyewa Tanah", Kertha Semaya, Vol. 03, No. 04, Mei 2019, h. 2, (URL: https://ojs.unud.ac.id/index.php/kerthasemaya/article/view/13345), diakses pada tanggal 5 Mei 2019.
} 
bahwa para pihak yang melakukan perjanjian dapat membatalkan perjanjian yang telah disepakati apabila pembatalan perjanjian tersebut didasarkan atas kesepakatan para pihak untuk membatalkannya dengan alasan tertentu atau alasan tersebut dinyatakan cukup oleh undang-undang. Pada Pasal 1266 dan Pasal 1267 KUH Perdata mengatur mengenai pembatalan perjanjian apabila salah satu pihak tidak memenuhi prestasi yang telah ditetapkan dalam perjanjian tersebut. Pada Pasal 1266 KUH Perdata dinyatakan bahwa perikatan yang lahir karena perjanjian baik itu perjanjian tertulis maupun perjanjian tidak tertulis (lisan) dapat dilakukan pemutusan perjanjian apabila terdapat 1 (satu) atau lebih kewajiban yang tercantum dalam perjanjian yang seharusnya dipenuhi namun ternyata tidak dipenuhi oleh salah satu pihak dapat dimintakan pembatalan ke pengadilan. ${ }^{3}$ Perjanjian yang diatur pada KUH Perdata dapat diakhiri sebelum berakhirnya waktu yang telah ditentukan apabila perjanjian tersebut nantinya akan menimbulkan kerugian terhadap para pihak, salah satu pihak, atau pihak lain. ${ }^{4}$ Pada prakteknya masih ada pihak yang melakukan pembatalan perjanjian secara sepihak pada sewa menyewa busana dalam merias wajah yang tidak sesuai dengan peraturan hukum yang ada, yaitu pihak penyewa pada Rat Ayu Wedding.

Berdasarkan permasalahan tersebut maka dilakukan penelitian yang berjudul, "Pelaksanaan Perjanjian Sewa Menyewa Busana Dalam Merias Wajah".

\footnotetext{
${ }^{3}$ Kartini Muljadi dan Gunawan Widjaja, 2003, Perikatan pada Umumnya, Ed. 1, cet. I, Rajawali Pers, Jakarta, h. 134.

${ }^{4}$ Ibid.
} 


\subsection{Rumusan Masalah}

1. Faktor-faktor apa yang mempengaruhi pembatalan perjanjian secara sepihak pada sewa menyewa busana dalam merias wajah?

2. Bagaimanakah penyelesaian terhadap pembatalan perjanjian secara sepihak pada sewa menyewa busana dalam merias wajah?

\subsection{Tujuan Penelitian}

Penelitian ini memiliki 2 (dua) tujuan yang hendak dicapai, yaitu tujuan umum dan tujuan khusus, yaitu untuk mengetahui dan memahami faktor-faktor yang mempengaruhi pembatalan perjanjian secara sepihak pada sewa menyewa busana dalam merias wajah dan penyelesaian terhadap pembatalan perjanjian secara sepihak pada sewa menyewa busana dalam merias wajah.

\section{Pembahasan dan Isi Makalah}

\subsection{Metode Penelitian}

1. Jenis Penelitian

Penelitian ini merupakan penelitian hukum empiris. Penelitian hukum empiris disebut juga sebagai penelitian lapangan karena menggunakan data yang didapatkan langsung dari lapangan. ${ }^{5}$ Penelitian hukum empiris adalah suatu penelitian lapangan yang dilakukan karena adanya kesenjangan antara praktek yang terjadi di masyarakat dengan peraturan hukum.

\footnotetext{
${ }^{5}$ Arif Sumantri, 2013, Metodologi Penelitian Hukum, PT Rajagrafindo Persada, Jakarta, h.7
} 


\section{Jenis Pendekatan}

Jenis pendekatan yang digunakan, yaitu pendekatan perundang-undangan (The Statue Approach) dan pendekatan fakta (The Fact Approach). Pendekatan perundang-undangan (The Statue Approach) adalah suatu pendekatan yang dilakukan dengan cara melakukan penyelidikan, menguraikan, dan menjabarkan peraturan perundang-undangan yang mengatur permasalahan tersebut. ${ }^{6}$ Pendekatan fakta (The Fact Approach) dilakukan dengan cara mengamati dan memahami permasalahan yang terjadi di lapangan.

\section{Sifat Penelitian}

Penelitian ini bersifat deskriptif yang artinya, bahwa penelitian ini memberikan penjelasan dengan cara memaparkan fakta sesungguhnya yang terjadi di masyarakat.

4. Data dan Sumber Data

Data yang digunakan, yaitu data primer dan data sekunder. Data primer adalah data yang peroleh di masyarakat. Data sekunder yang digunakan dalam penelitian ini, yaitu bahan hukum primer, bahan hukum sekunder, dan bahan hukum tersier.

\section{Teknik Pengumpulan Data}

Teknik pengumpulan data mempengaruhi keakuratan data yang diperoleh. Teknik pengumpulan data yang digunakan, yaitu teknik studi dokumen dan teknik wawancara. Teknik studi dokumen adalah teknik pengumpulan data yang dilakukan dengan cara menelaah bahan hukum primer, bahan hukum sekunder, dan bahan hukum tersier. Teknik wawancara adalah suatu kegiatan pengumpulan data yang dilakukan dengan cara mengajukan

\footnotetext{
${ }^{6}$ Amiruddin dan Zainal Asikin, 2016, Pengantar Metode Penelitian Hukum, cet. IX, PT Rajagrafindo Persada, Jakarta, h. 164.
} 
pertanyaan oleh interviewer (pewawancara) kepada narasumber/responden. ${ }^{7}$

6. Teknik Pengolahan dan Analisis Data

Peneliti harus memiliki tingkat kecermatan dan ketelitian yang tinggi saat melakukan pengolahan dan analisis data. Pengolahan dan analisis data dalam penelitian ini, yaitu dilakukan secara kualitatif. Analisis data dilakukan secara kualitatif karena data berbentuk kasus-kasus yang terjadi di lapangan. 8

\subsection{Hasil dan Pembahasan}

\subsubsection{Faktor-Faktor yang Mempengaruhi Pembatalan Perjanjian Secara Sepihak pada Sewa Menyewa Busana dalam Merias Wajah}

Perjanjian dilakukan antara pihak yang menyewakan dan pihak penyewa menimbulkan suatu hubungan untuk mempermudah dan memperlancar para pihak dalam berinteraksi. ${ }^{9}$ Perjanjian sewa menyewa merupakan bagian dari perjanjian bernama. Perjanjian sewa menyewa adalah suatu perjanjian yang dilakukan antara para pihak, yaitu pihak pemilik barang memberikan kepada pihak lain untuk dapat menggunakan dan menikmati barang tersebut berdasarkan jangka waktu yang telah disepakati dan pihak yang menggunakan dan menikmati barang wajib memberikan bayaran kepada pemilik barang sesuai dengan kesepakatan yang telah

\footnotetext{
${ }^{7}$ Ibid.

${ }^{8}$ Koenjaraningrat, 1989, Metode Penelitian Masyarakat, cet. XI, PT Gramedia, Jakarta, h. 269.

9 Rantika Andreani, I Wayan Wiryawan, dan Dewa Gde Rudy, 2015, "Akibat Hukum Pemutusan Perjanjian Sewa Menyewa Global Positioning System (GPS) oleh Konsumen PT Kreasi Sejahtera Teknologi Dalam Masa Perjanjian Belum Berakhir”, Kertha Semaya, Vol. 03, No. 03, Mei 2015, (URL: https://ojs.unud.ac.id/index.php/kerthasemaya/article/view/13160), diakses pada tanggal 28 April 2019 pukul 17.26
} 
ditetapkan. ${ }^{10}$ Berdasarkan Pasal 1548 KUH Perdata menyebutkan bahwa, "Sewa menyewa adalah suatu perjanjian yang para pihak, yaitu penyewa dan pihak yang menyewakan mengikat diri untuk memberikan suatu barang untuk dinikmati oleh pihak penyewa berdasarkan waktu tertentu dan pihak penyewa memberikan bayaran atas barang yang disewa kepada pihak yang menyewakan". Sewa menyewa merupakan perjanjian konsesualisme yang artinya bahwa perjanjian tersebut hanya dapat terjadi ketika ada kesepakatan antara para pihak. ${ }^{11}$

Suatu perjanjian agar dapat dikatakan sebagai perjanjian sewa menyewa harus memenuhi unsur-unsur, yaitu adanya para pihak yang membuat perjanjian sewa menyewa, yaitu pihak penyewa dan pihak yang menyewakan, para pihak sepakat untuk melakukan perjanjian, pihak penyewa wajib memberikan barang yang disewa kepada pihak penyewa untuk dinikmati, dan pihak penyewa memiliki kewajiban untuk membayar barang yang disewa kepada pihak yang menyewakan sesuai dengan harga yang telah disepakati oleh kedua belah pihak.

Perjanjian sewa menyewa dapat dilakukan dalam bentuk tertulis dan tidak tertulis (lisan). Perjanjian tertulis adalah suatu kontrak yang dibuat di atas kertas yang isinya ditentukan oleh kedua belah pihak atau salah satu pihak, sedangkan perjanjian lisan adalah perjanjian yang dibuat dengan cara mengucap kata sepakat serta hak dan kewajiban para pihak dipaparkan secara lisan. Perjanjian sewa menyewa dilakukan dalam bentuk tertulis diatur dalam Pasal 1570 KUH Perdata yang menyetakan bahwa, perjanjian sewa menyewa

\footnotetext{
${ }^{10}$ I Ketut Oka Setiawan, 2016, Hukum Perikatan, cet. I, Sinar Grafika, Jakarta, h. 179.

${ }^{11}$ Herlien Budiono, 2014, Ajaran Umum Hukum Perjanjian dan Penerapannya di Bidang Kenotariatan, PT Citra Aditya Bakti, Bandung, h. 40.
} 
tersebut berakhir sesuai dengan yang telah ditentukan dalam perjanjian tersebut, yaitu apabila waktu yang telah ditentukan telah habis. Perjanjian sewa menyewa yang dilakukan dalam bentuk lisan diatur dalam Pasal 1571 KUH Perdata yang menyebutkan bahwa perjanjian sewa menyewa berakhir saat salah satu pihak menghentikan sewanya dan memberitahu kepada pihak lain bahwa ia hendak menghentikan perjanjian sewa menyewa.

Perjanjian sewa menyewa dapat dilakukan dalam berbagai hal seperti halnya perjanjian sewa menyewa busana dalam merias wajah. Pada umumnya perjanjian sewa menyewa dalam merias wajah dilakukan secara lisan seperti perjanjian sewa menyewa yang dilakukan antara Rat Ayu Wedding sebagai pihak yang menyewakan dengan pihak penyewa. Ibu Luh Sudarmini yang merupakan pekerja di Rat Ayu Wedding menjelaskan bahwa perjanjian sewa menyewa dalam merias wajah dilakukan secara tidak tertulis karena untuk mempermudah dalam membuat perjanjian tersebut karena perjanjian tersebut didasarkan atas adanya unsur kepercayaan didalamnya dan masih tabu apabila perjanjian sewa menyewa busana dalam merias wajah dibuat dalam bentuk tertulis. (Wawancara pada Tanggal 18 April 2019)

Pada perjanjian sewa menyewa busana dalam merias wajah sering terjadi pembatalan perjanjian secara sepihak yang dilakukan oleh pihak penyewa. Pembatalan perjanjian secara sepihak pada sewa menyewa busana dalam merias wajah dipengaruhi oleh 2 (dua) faktor, yaitu faktor internal dan faktor eksternal. Faktor internal adalah suatu faktor pendukung yang berasal dari dalam diri pihak penyewa. Faktor internalnya, yaitu kurangnya pengetahuan yang dimiliki oleh masyarakat mengenai kekuatan hukum pada perjanjian 
tidak tertulis bahwa sesungguhnya perjanjian tersebut memiliki kekuatan hukum yang sama dengan perjanjian tertulis dengan syarat dapat dibuktikan bahwa perjanjian tidak tertulis tersebut benar terjadi.

Faktor eksternal adalah faktor pendukung yang berasal dari luar diri penyewa. Faktor eksternalnya, yaitu pertama, terdapat tempat lain yang menyewakan busana dan rias wajah dengan harga yang lebih murah dibandingkan dengan tempat sebelumnya. Kedua, busana yang disewa cacat karena adanya kelalaian yang disebabkan oleh pihak yang menyewakan dan/atau pihak penyewa yang terdahulu seperti busana robek, warna busana luntur, dan lain sebagainya. Padahal dalam perjanjian sewa menyewa, pihak penyewa memiliki kewajiban untuk menjaga dan memelihara barang yang disewa seperti ia menjaga dan memelihara barang miliknya karena penyerahan barang yang dilakukan dalam perjanjian sewa menyewa tidak serta merta menyebabkan barang tersebut menjadi milik pihak penyewa tetapi penyewa hanya diberi kesempatan untuk menggunakan dan menikmati barang yang disewa tersebut. ${ }^{12}$ Ketiga, busana yang disewa oleh penyewa belum dikembalikan oleh pihak penyewa yang terdahulu.

\subsubsection{Penyelesaian Terhadap Pembatalan Perjanjian Secara Sepihak pada Sewa Menyewa Busana dalam Merias Wajah}

Pada umumnya penyelesaian yang dilakukan apabila terjadi pembatalan perjanjian secara sepihak pada sewa menyewa busana

${ }^{12}$ A. A. Indah Kusuma Dewi dan Made Suksma Prijandhini Salain, 2016, "Perjanjian Sewa Menyewa Rumah antara Pihak Menyewakan dan Pihak Penyewa di Kota Denpasar", Vol. 04, No. 04, Juli 2016, h. 2, (https://ojs.unud.ac.id/index.php/kerthasemaya/article/view/21821), diakses pada tanggal 5 Mei 2019 pukul 19.05 
dalam merias wajah, yaitu diselesaikan secara kekeluargaan. Seperti yang disampaikan oleh Ibu Luh Sudarmini bahwa penyelesaian pembatalan perjanjian secara sepihak pada sewa menyewa busana dalam merias wajah dilakukan dengan cara kekeluargaan karena dirasa paling mudah dan tidak berbelit-belit mengingat kesibukan yang dimiliki oleh pihak yang menyewakan. Apabila penyelesaian ini dilakukan melalui pengadilan akan membutuhkan waktu dan proses yang panjang. (Wawancara pada tanggal 18 April 2019)

Penyelesaian yang dilakukan secara kekeluargaan memberikan rasa adil dan hasil yang lebih memuaskan dibandingkan penyelesaian yang dilakukan melalui pengadilan karena yang menentukan pertanggungjawaban akibat dari pembatalan perjanjian secara sepihak yang dilakukan pihak penyewa adalah pihak yang menyewakan dengan pihak penyewa.

Pihak yang menyewakan meminta pertanggungjawaban dari pihak penyewa karena perbuatan yang dilakukan pihak penyewa menimbulkan kerugian materiil. Kerugian yang dialami Rat Ayu Wedding akibat dari pembatalan perjanjan secara sepihak pada sewa menyewa busana dalam merias wajah, yaitu mulai Rp 200.000,. s/d Rp 12.000.000,. bahkan lebih tergantung harga busana yang disewa dan harga rias wajah yang digunakan. Kerugian yang paling besar ketika ada pihak penyewa yang menyewa paket lengkap, yaitu sewa busana, rias wajah, dan photographer yang kemudian pihak penyewa secara tiba-tiba membatalkan perjanjian tersebut. Kerugian ini tidak hanya dirasakan oleh Rat Ayu Wedding tetapi juga dirasakan oleh photographer yang bekerja sama dengan Rat Ayu Wedding.

Pembatalan perjanjian secara sepihak pada sewa menyewa busana dalam merias wajah dikatakan merugikan Rat Ayu Wedding 
karena ketika pesanan sudah penuh maka mereka tidak menerima booking lagi. Apabila pada hari tertentu ada salah satu pihak penyewa yang membatalkan pesanan maka secara otomatis Rat Ayu Wedding mengalami kerugian karena adanya penurunan pendapatan perharinya.

Pembatalan perjanjian secara sepihak yang dilakukan penyewa di Rat Ayu Wedding tidak memenuhinya unsur 1266 KUH Perdata, yaitu bersifat timbal balik, adanya unsur wanprestasi di dalamnya, dan harus dimintakan pembatalahn ke hakim yang berwenang. Perjanjian sewa menyewa busana dalam merias wajah yang dilakukan antara Rat Ayu Wedding sebagai pihak yang menyewakan dengan pihak penyewa dapat dibatalkan secara sepihak oleh penyewa dengan syarat harus terpenuhinya unsur-unsur yang terdapat dalam Pasal 1266 KUH Perdata.

Akibat dari kerugian yang dialami Rat Ayu Wedding maka ia dapat meminta pihak penyewa untuk memenuhi prestasinya, melaksanakan prestasi yang disertai ganti rugi, atau pembatalan perjanjian sewa menyewa yang disertai dengan kewajiban penyewa membayar ganti rugi. Jumlah ganti rugi diberikan tergantung pada banyak sedikitnya kerugian yang dialami dan besar kecilnya keuntungan yang harus diterima jika tidak terjadi kerugian. Mengenai jumlah ganti rugi yang harus dibayar oleh pihak penyewa busana dalam merias wajah ditentukan berdasarkan kesepakatan para pihak. Penyebab pembatalan perjanjian secara sepihak dapat dijadikan sebagai pertimbangan dalam menentukan jumlah ganti rugi. Pihak yang menyewakan juga memberikan sanksi kepada penyewa yang membatalkan perjanjian secara sepihak, yaitu dilarang menggunakan jasa Rat Ayu Wedding. 


\section{Penutup}

\subsection{Kesimpulan}

1. Faktor-faktor yang mempengaruhi pembatalan perjanjian secara sepihak pada sewa menyewa busana dalam merias wajah ada 2 (dua), yaitu faktor internal dan faktor eksternal. Faktor internalnya, yaitu kurangnya pengetahuan mengenai perjanjian tidak tertulis bahwa perjanjian jenis ini memiliki kekuatan hukum. Faktor eksternalnya, yaitu terdapat tempat lain yang menyewakan busana dan rias wajah lebih murah, busana yang disewa cacat yang disebabkan oleh pihak yang menyewakan dan/atau pihak penyewa terdahulu, dan busana yang disewa oleh pihak penyewa belum dikembalikan oleh pihak penyewa terdahulu.

2. Penyelesaian terhadap pembatalan perjanjian secara sepihak pada sewa menyewa busana dalam merias wajah dilakukan dengan cara kekeluargaan yang disertai dengan diwajibkannya pihak penyewa untuk melaksanakan prestasi, melaksanakan prestasi disertai ganti rugi, atau perjanjian dibatalkan disertai pemberian ganti rugi. Pihak penyewa juga diberikan sanksi oleh pihak yang menyewakan, yaitu dilarang menggunakan jasa Rat Ayu Wedding.

\subsection{Saran}

1. Agar pihak penyewa mentaati peraturan hukum yang ada khususnya yang mengatur mengenai perjanjian sewa menyewa dan pihak penyewa memenuhi isi perjanjian sewa 
menyewa sehingga tidak ada lagi pembatalan perjanjian secara sepihak pada sewa menyewa busana dalam merias wajah yang dapat merugikan salah satu pihak.

2. Agar pihak yang menyewakan membuat perjanjian dalam bentuk tertulis untuk lebih memudahkan dalam proses pembuktian apabila salah satu pihak melakukan pembatalan perjanjian secara sepihak pada perjanjian sewa menyewa dalam merias wajah. 


\section{DAFTAR PUSTAKA}

\section{Buku}

Amiruddin, Zainal Asikin, 2016, Pengantar Metode Penelitian Hukum, cet. IX, PT. Rajagrafindo Persada, Jakarta.

I Ketut Artadi, I Dw. Nym. Rain Asmara P., 2010, Implementasi Ketentuan-Ketentuan Hukum Perjanjian Kedalam Perancangan Kontrak, Udayana Press, Denpasar.

Kartini Muljadi, Gunawan Widjaja, 2003, Perikatan Pada Umumnya, ed. 1, cet. I, Rajawali Pers, Jakarta.

Koenjaroningrat, 1989, Metode Penelitian Masyarakat, cet. IX, PT. Gramedia, Jakarta.

Setiawan, I Ketut Oka, 2016, Hukum Perikatan, cet. I, Sinar Grafika, Jakarta.

Sumantri, Arif, 2003, Metodologi Penelitian Hukum, PT. Rajagrafindo Persada, Jakarta.

\section{Artikel Online}

A.A. Dalem Jagat Krisno, Ni Ketut Supasti Dharmawan, dan A. A. Sagung Wiratni Darmadi, 2015, "Akibat Hukum yang Ditimbulkan Dari Wanprestasi Dalam Perjanjian Autentik SewaMenyewa Tanah", Kertha Semaya, Vol. 03, No. 04, Mei 2015, (URL:

https://ojs.unud.ac.id/index.php/kerthasemaya/article/view/1 3345), diakses pada tanggal 5 Mei 2019 pukul 18.15

A.A Indah Kusuma Dewi dan Made Suksma Prijandhini Salain, 2016, "Perjanjian Sewa Menyewa Rumah Antara Pihak Menyewakan dan Pihak Penyewa di Kota Denpasar", Vol. 04, No. 04, Juli 2016,

(URL: https://ojs.unud.ac.id/index.php/kerthasemaya/article/view/2 1821), diakses pada tanggal 5 Mei 2019 pukul 19.05

Rantika Andreani, I Wayan Wiryawan, dan Dewa Gde Rudy, 2015, "Akibat Hukum Pemutusan Perjanjian Sewa Menyewa Global 
Positioning System (GPS) Oleh Konsumen PT. Kreasi Sejahtera Teknologi Dalam Masa Perjanjian Belum Berakhir". Kertha Semaya, Vol. 03, No. 03, Mei 2015, (URL: https://ojs.unud.ac.id/index.php/kerthasemaya/article/view/1 3160), diakses pada tanggal 28 April 2019 pukul 17.29

\section{Peraturan Perundang-Undangan}

Indonesia, Kitab Undang-Undang Hukum Pardata (KUH Perdata), Terjemahan dari Burgerlijk Webook, Subekti dan Tjitrosudibio, 2008, Pradnya Paramita, Jakarta. 